REPORTS OF MORPHOLOGY
Official Journal of the Scientific Society of Anatomists,
Histologists, Embryologists and Topographic Anatomists
of Ukraine
journal homepage: https://morphology-journal.com

\title{
Use of azimuthal-invariant Mueller-matrix images of linear dichroism of histological sections of brain substance for diagnosis of hemorrhage genesis
}

\author{
Garazdiuk M.S. ${ }^{1}$, Dubolazov O.V. ${ }^{2}$, Malanchuk S.M. ${ }^{3}$
}

${ }_{1}^{1}$ Bukovinian State Medical University, Chernivtsi, Ukraine

${ }^{2}$ Institute of Physical, Technical and Computer Sciences of Chernivtsi National University named after Yu. Fedkovych, Chernivtsi, Ukraine ${ }^{3}$ Municipal Non-Commercial Enterprise "City Children's Polyclinic" Chernivtsi City Council, Chernivtsi, Ukraine

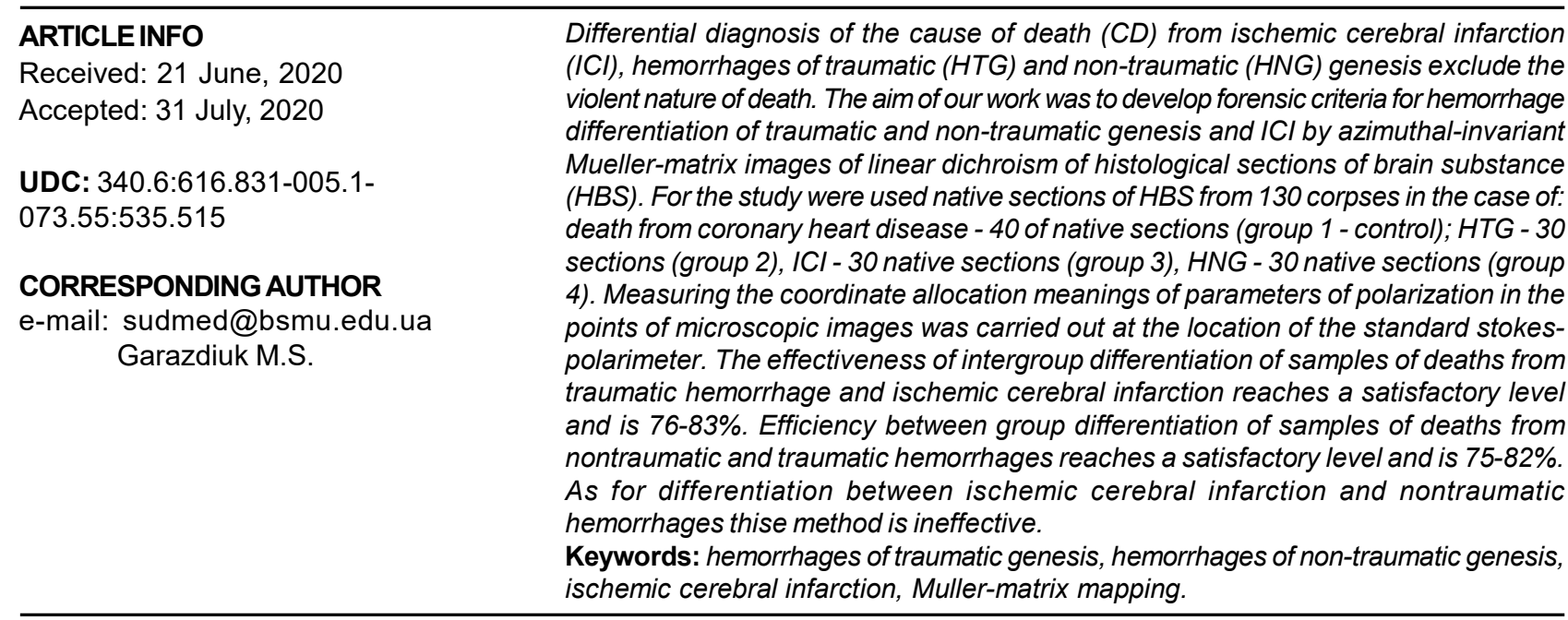

\section{Introduction}

Traumatic brain injury is one of the most common types of mechanical damage to the human body $[7,8,9,10,12$, 24]. Quite often, in forensic practice there are cases when the body was found at home under unexplained circumstances and later during the autopsy hemorrhage into the substance of the human brain (HBS) was detected. In this case forensic authorities raise questions about the genesis of hemorrhage: traumatic or non-traumatic. There are studies in which it is noted that traumatic brain injury (TBI) and strokes can coexist or occur one on background of another one, which further complicates the situation [22]. Therefore, differential diagnosis of the cause of death (CD) from ischemic cerebral infarction (ICI), hemorrhages of traumatic (HTG) and non-traumatic (HNG) genesis excluded the violent nature of death $[10,12,23]$. It should also be noted that the incidence of hemorrhage in the brain necessitates the study of structural alterations of HBS and the determination of reliable criteria for hemorrhage differentiation.

Typically, physicians in routine practice for differential diagnosis within the group of acute cerebrovascular disorders use computed tomography (CT) and general clinical data, but there is very little data on the differentiation of strokes of ischemic and hemorrhagic genesis and hemorrhage in HBS of traumatic origin [10, 12, 24]. A team of scientists led by Panzer $S$ noted the feasibility of performing pre-mortem CT to compare it with CT immediately after injury of HBS, as well as the subsequent comparison of all CT images with autopsy results [10]. Comparison between primary $\mathrm{CT}$ and recent $\mathrm{CT}$ scans revealed marked changes in the presence and severity of signs of HBS injury, especially in patients with severe TBI. They also noted that the comparison of autopsy and CT data revealed a high level of diagnostic specificity $(\geq 80 \%)$ 
in the studied cases.

Recently in forensic practice optical methods of biological tissue research using lasers have positively proved themselves, which by studying the phenomena of light scattering make it possible to obtain reliable objective data of the dynamics of pre- and post-mortem changes of the studied tissues of the human body and to diagnose with greater accuracy prescription of pathological process in biological tissues and liquids [1, 2, 3, 4, 5, 11, 13, 14, 15, $16,17,18,19,20,21]$.

The aim of our work: was to develop forensic criteria for hemorrhage differentiation of traumatic and non-traumatic genesis and $\mathrm{ICI}$ by azimuthal-invariant Mueller-matrix images of linear dichroism of histological sections of HBS.

\section{Materials and methods}

For the study were used native sections of HBS from 130 corpses in the case of: death from coronary heart disease - $40(31 \%)$ of native sections (group 1 - control); HTG - 30 (23\%) sections (group 2), ICl - 30 (23\%) native sections (group 3), HNG - 30 (23\%) native sections (group 4).

For the study, the preparations were previously subjected to rapid freezing, then histologic sections were made. Subsequently, the samples were sent to the laboratory of the Yuriy Fedkovych Institute of Physical, Technical and Computer Sciences, where they were investigated using the azimuthal-invariant Muller-matrix mapping method, the way of application of the method is described in sources [5, 13, 15].

Measuring the coordinate allocation meanings of parameters of polarization in the points of microscopic images was carried out at the location of the standard stokes-polarimeter [3].

Experimental measurements of Stokes-parametric images of biological layers were carried out according to the method presented in these publications $[3,5,15]$.

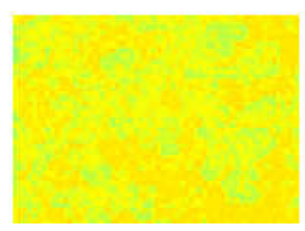

(1)

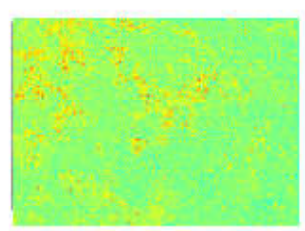

(5)

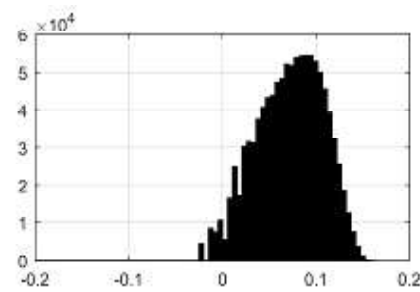

(2)

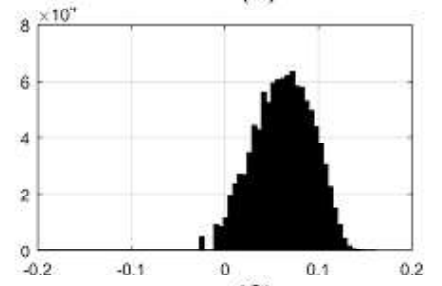

(6)

Subsequently, statistical processing of the obtained data was performed [6].

\section{Results}

Figure 1 shows Results of azimuthal-invariant Muellermatrix mapping of topographic maps (fragments (1), (3), (5), (7)) and histograms of probability distribution values(fragments (2), (4), (6), (8) )of Mueller-matrix invariant (MMI) of linear dichroism (LD), which characterizes the polarization manifestations of linear dichroism of spatial structured fibrillar networks of nervous tissue of the deceaseds from groups 1-4.

A comparative analysis of the results of the Muller-matrix mapping of the polarization manifestations of LD of fibrillar networks of brain samples revealed: significant topographic heterogeneity of MMI LD maps of histological sections of the brain of the dead from all groups (Fig. 1, Fragments (1), (3), (5), (7)); series of distributions of the value of MMI LD fibrillar networks of samples of histological sections of the brain from all (control 1 and experimental 2-4) groups are characterized by individual and significant variations in the magnitude of the central statistical moments of the 2 nd 4th orders (Fig. 1, Fragments (2), (4), (6), (8)).

Table 1 shows the statistical analysis of MMI of LD maps of HBS.

Comparison of statistical analysis data revealed diagnostic sensitivity of the set of central statistical moments of the 2nd - 4th orders (highlighted in gray - Table 1) for azimuthal-invariant Mueller-matrix differentiation of manifestations of linear dichroism of spatially structured fibrillar networks of samples of nerve tissue samples both control group 1 and all experimental groups $2-4(p<0.05)$. Along with this, there are possibility of intergroup (experimental groups 2-4) statistical differentiation of coordinate distributions of the MMI of LD of experimental representative samples of histological sections of the brain

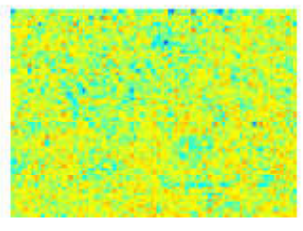

(3)

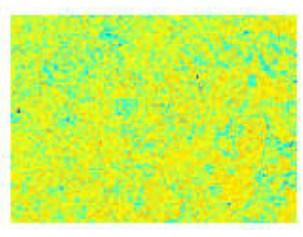

(7)

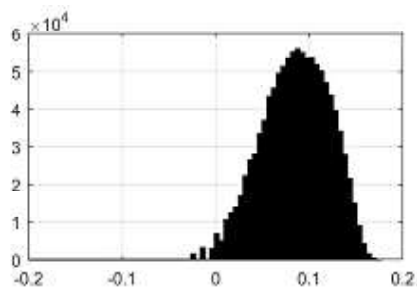

(4)

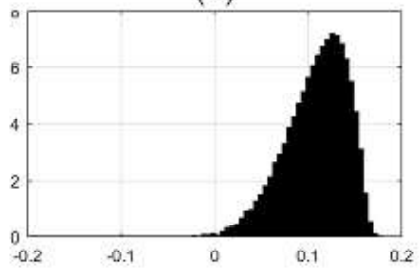

(8)

Fig. 1. Maps ((1), (3), (5), (7)) and histograms ((2), (4), (6), (8)) of the magnitudes of the distributions of the MMI LB of HBS histological sections from group $1((1),(2))$, group $2((3),(4))$, group $3((5),(6))$ and group $4((7),(8))$. 
Table 1. Statistical moments of 1-4-th order characterizing the MMI of $L D$ values distributions of histological sections of the brain of groups 1 - 4

\begin{tabular}{|c|c|c|c|c|}
\hline Parameters & Group 1 & Group 2 & Group 3 & Group 4 \\
\hline$S M_{1}$ & $0.240 \pm 0.009$ & $0.221 \pm 0.011$ & $0.251 \pm 0.01$ & $0.210 \pm 0.008$ \\
\hline$p_{1}$ & & $p<0.05$ & $p<0.05$ & $p<0.05$ \\
\hline$p_{2}$ & & \multicolumn{2}{|l|}{$p>0.05$} & $p>0.05$ \\
\hline$p_{3}$ & & $p>0.05$ & \multicolumn{2}{|l|}{$p>0.05$} \\
\hline$p_{4}$ & & \multicolumn{3}{|l|}{$p>0.05$} \\
\hline$S M_{2}$ & $0.212 \pm 0.011$ & $0.271 \pm 0.017$ & $0.321 \pm 0.016$ & $0.370 \pm 0.014$ \\
\hline$p_{1}$ & & $p<0.05$ & $p<0.05$ & $p<0.05$ \\
\hline$p_{2}$ & & \multicolumn{2}{|l|}{$p>0.05$} & $p>0.05$ \\
\hline$p_{3}$ & & $p>0.05$ & \multicolumn{2}{|l|}{$p>0.05$} \\
\hline$p_{4}$ & & \multicolumn{3}{|l|}{$p>0.05$} \\
\hline$S M_{3}$ & $0.691 \pm 0.027$ & $0.872 \pm 0.034$ & $0.981 \pm 0.035$ & $1.110 \pm 0.044$ \\
\hline$p_{1}$ & & $p<0.05$ & $p<0.05$ & $p<0.05$ \\
\hline$p_{2}$ & & \multicolumn{2}{|l|}{$p>0.05$} & $p<0.05$ \\
\hline$p_{3}$ & & $p>0.05$ & \multicolumn{2}{|l|}{$p>0.05$} \\
\hline$p_{4}$ & & \multicolumn{3}{|l|}{$p>0.05$} \\
\hline$S M_{4}$ & $0.891 \pm 0.041$ & $1.120 \pm 0.048$ & $1.221 \pm 0.051$ & $1.431 \pm 0.059$ \\
\hline$p_{1}$ & & $p<0.05$ & $p<0.05$ & $p<0.05$ \\
\hline$p_{2}$ & & \multicolumn{2}{|l|}{$p>0.05$} & $p>0.05$ \\
\hline$p_{3}$ & & $p>0.05$ & \multicolumn{2}{|l|}{$p>0.05$} \\
\hline$p_{4}$ & & \multicolumn{3}{|c|}{$p>0.05$} \\
\hline
\end{tabular}

- "group 2 - group 4" $(p<0.05)$ and "group 2 and group 3" $(\mathrm{p}<0.05)$.

The values of operational characteristics that characterize the strength of the method of azimuthalinvariant Mueller-matrix polarimetry of the distributions of the linear dichroism of a set of brain tissue samples for objective statistical differentiation of causes of death are presented in table 2.

An increase in the value of sensitivity, specificity and balanced accuracy by $14-19 \%$ compared with the data of the Muller-matrix polarimetry of distributions of the Mullermatrix invariant of linear birefringence of samples of HBS $[14,16]$.

For a set of central statistical moments of the 1st, 3rd and 4 th orders, which characterize the distributions of circular dichroism, the method of Mueller matrix microscopy in the differentiation of samples of control and experimental groups reaches a satisfactory level $78-84 \%$.

Between control group 1 (ischemic heart disease) and all experimental groups 1-3 the azimuthal-invariant Mullermatrix mapping of the polarization manifestations of LB of fibrillary nerve tissue networks of the dead demonstrates a good level of differentiation, which is $79-83 \%$.

Diagnostic efficiency of the Mueller-matrix mapping method of polarization manifestations of LD for intergroup differentiation of samples of deaths from HTG (group 2) and $\mathrm{ICl}$ (group 3) reaches a satisfactory level and is 76$83 \%$. A similar (satisfactory $75-82 \%$ ) level of differentiation is achieved for samples of histological sections of deaths from HNG (group 4) and HTG (group 2).

As for differentiation between $\mathrm{ICl}$ (group 3) and HNG (group 4) thise method is ineffective, as the level of differentiation is from 60 to $70 \%$.

Table 2. Specificity, sensitivity, accuracy of the method of statistical analysis of MMI of LB maps of histological sections of the brain.

\begin{tabular}{|c|c|c|c|}
\hline \multicolumn{4}{|c|}{ Groups "1 - 2+3+4" } \\
\hline Parameters & sensitivity Se, \% & specificity Sp, \% & accuracy Ac, \% \\
\hline \multirow{2}{*}{$S M_{1}$} & $a=99 ; b=31$ & $c=93 ; d=37$ & $n=130$ \\
\hline & 80 & 75 & 77,5 \\
\hline \multirow{2}{*}{$S M^{2}$} & $a=99 ; b=31$ & $c=93 ; d=37$ & $n=130$ \\
\hline & 80 & 75 & 77,5 \\
\hline \multirow{2}{*}{$S M_{3}$} & $a=108 ; b=22$ & $c=105 ; d=25$ & $n=130$ \\
\hline & 83 & 79 & 81 \\
\hline \multirow{2}{*}{$S M_{4}$} & $a=108 ; b=22$ & $c=105 ; d=25$ & $n=130$ \\
\hline & 83 & 79 & 81 \\
\hline \multicolumn{4}{|c|}{ Groups "2 - 3" } \\
\hline \multirow{2}{*}{$S M_{1}$} & $a=90 ; b=40$ & $c=102 ; d=28$ & $n=130$ \\
\hline & 69 & 64 & 66,5 \\
\hline \multirow{2}{*}{$S M^{2}$} & $a=90 ; b=40$ & $c=102 ; d=28$ & $n=130$ \\
\hline & 69 & 64 & 66,5 \\
\hline \multirow{2}{*}{$S M_{3}$} & $a=108 ; b=22$ & $c=99 ; d=31$ & $n=130$ \\
\hline & 83 & 76 & 79,5 \\
\hline \multirow{2}{*}{$S M_{4}$} & $a=108 ; b=22$ & $c=99 ; d=31$ & $n=130$ \\
\hline & 83 & 76 & 79,5 \\
\hline \multicolumn{4}{|c|}{ Groups "2 - 4" } \\
\hline \multirow{2}{*}{$S M_{1}$} & $a=82 ; b=48$ & $c=78 ; d=52$ & $n=130$ \\
\hline & 63 & 60 & 61,5 \\
\hline \multirow{2}{*}{$S M^{2}$} & $a=82 ; b=48$ & $c=81 ; d=49$ & $n=130$ \\
\hline & 65 & 62 & 63,5 \\
\hline \multirow{2}{*}{$S M_{3}$} & $a=107 ; b=23$ & $c=98 ; d=32$ & $n=130$ \\
\hline & 82 & 75 & 78,5 \\
\hline \multirow{2}{*}{$S M_{4}$} & $a=107 ; b=23$ & $c=98 ; d=32$ & $n=130$ \\
\hline & 82 & 75 & 78,5 \\
\hline \multicolumn{4}{|c|}{ Groups "3 - 4" } \\
\hline \multirow{2}{*}{$S M_{1}$} & $a=82 ; b=48$ & $c=78 ; d=52$ & $n=130$ \\
\hline & 63 & 60 & 61,5 \\
\hline \multirow{2}{*}{$S M^{2}$} & $a=82 ; b=48$ & $c=79 ; d=51$ & $n=130$ \\
\hline & 63 & 61 & 62 \\
\hline \multirow{2}{*}{$S M_{3}$} & $a=87 ; b=43$ & $c=82 ; d=48$ & $n=130$ \\
\hline & 67 & 63 & 65 \\
\hline \multirow{2}{*}{$S M_{4}$} & $a=87 ; b=43$ & $C=82 ; d=48$ & $n=130$ \\
\hline & 67 & 63 & 65 \\
\hline
\end{tabular}




\section{Discussion}

Methods of polarization tomography, based on the results of numerical display of instrumental measurement of parameters, are one of the most objective and accurate for recording changes that occurred in a biological object under the influence of environmental factors and changes in biological tissues (BT) during the pathological process. They also have the main requirement for the introduction of modern research methods in the practice of any expert field - the ability not to change the properties and condition of the object under study in its evaluation [3, 19, 20, 21].

The method of polarization laser microscopy allows to obtain important information about the morphological structure and properties of human BT. From the optical point of view on BT they consist of 2 phases: amorphous and optically anisotropic (crystalline) [3]. Crystal structures include coaxial fibrils, which form collagen, elastin, myosin organic fibers, surrounded by fluids and media of the human body. An important feature of these fibrillar proteins is their clear order. It should be noted that polarization

\section{References}

[1]Angelsky, O. V., Ushenko, Y. A., \& Balanetska, V. O. (2011). The degree of mutual anisotropy of biological liquids polycrystalline nets as a parameter in diagnostics and differentiations of hominal inflammatory processes. Proc. SPIE 8338. In Tenth International Conference on Correlation Optics. 83380S. doi: $10.1117 / 12.920065$

[2] Angelsky, O. V., Ushenko, A. G., Angelska, A. O., \& Ushenko, Y. A. (2007). Polarization correlometry of polarization singularities of biological tissues object fields. Proc. SPIE 6616, Optical Measurement Systems for Industrial Inspection. 66160V. doi: $10.1117 / 12.725980$

[3] Bachinskiy, V. T., Boichuk, T. M. \& Ushenko, A. G. (2017). Laser polarimetry of biological tissues and fluids. LAP LAMBERT Academic Publishing.

[4] Bachynskyi, V. T., Hurov, O. M., Sarkisova, Yu. V., \& Ushenko, O. H. (2017). Basic principles of morphological assessment of the state of biological tissues using laser polarimetric methods for solving forensic medicine problems. Clinical and experimental pathology, 16(1), 20-23.

[5] Garazdyuk, M., Savka, I., Tomka, Y., Soltys, I., Dubolazov, O., \& Dvorjak, V. (2020). Azimuthally invariant Mueller-matrix microscopy in the differential diagnosis of cerebral infarction. In Optics and Photonics for Information Processing XIV (Vol. 11509 , p. 115090T). International Society for Optics and Photonics. doi: 10.1117/12.2568436

[6] Glanc, S. (1999). Biomedical statistics. M.: Praktika.

[7] Finnie, J.W. (2016) Forensic Pathology of Traumatic Brain Injury. Vet. Pathol., 53(5), 962-978. doi: 10.1177/0300985815612155

[8] Hohlov, V. V. (2010). Forensic Medicine: A Guide. Smolensk.

[9] Konovalov, A. N., Lihtermana, L. B. \& Potapova, A. A. (Ed.). (2001). Clinical Guide to Traumatic Brain Injury. M.: Antidor.

[10] Panzer, S., Covaliov, L., Augat, P. \& Peschel, O. (2017) Traumatic brain injury: Comparison between autopsy and ante-mortem CT. J. Forensic Leg. Med., 52, 62-69. doi: 10.1016/ j.jflm.2017.08.007

[11] Pavlyukovych, O. V. (2011). Determination of the age of death in some types of mechanical asphyxia and massive blood loss by laser polarimetry. Kyiv. microscopy carries information about the degree of ordering and crystallization of the structure of BT [3].

\section{Conclusions}

1. The magnitudes of operational characteristics that characterize the power of the method of azimuthal-invariant Mueller-matrix images of linear dichroism of histological sections of human brain substance demonstrate the possibility of objective statistically significant differences by this method.

2. The effectiveness of intergroup differentiation of samples of deaths from traumatic hemorrhage and ischemic cerebral infarction reaches a satisfactory level and is $76-83 \%$.

3. Efficiency between group differentiation of samples of deaths from nontraumatic and traumatic hemorrhages reaches a satisfactory level and is $75-82 \%$.

4. As for differentiation between ischemic cerebral infarction and nontraumatic hemorrhages thise method is ineffective.

[12] Pigolkina, E. Ju., Dorosheva, Zh. V., Sidorovich, V. \& Bychkov, A. A. (2012). Modern aspects of forensic diagnosis of traumatic brain injury. Forensic-medical examination, 55(1), 38-40.

[13] Ushenko, Y. A., Dubolazov, A. V., Karachevtsev, A. O., Sakhnovskiy, M. Y., Bizer, L. I., \& Bodnar, O. B. (2014). Multidimensional Mueller matrices microscopy of biological crystal networks structure. In: 7th International Workshop on Advanced Optical Imaging and Metrology Fringe 2013. New York: Springer.

[14] Ushenko, A. G., Dubolazov, A. V., Ushenko, Y. A., Tomka, Y. Y., Karachevtsev, A. O., Sidor, M. I. \& Prydiy, A. (2020). Differential diagnosis of the limitation of the formation of hemorrhages of traumatic origin, cerebral infarction, ischemic and hemorrhagic genesis by polarization-phase tomography. Proc. SPIE 0277-786X. In Fourteenth International Conference on Correlation Optics. 11369. doi: 10.1117/12.2553989

[15] Ushenko, A. G., Dubolazov, A. V., Ushenko, V. A., Ushenko, Y. A., Pidkamin, L. Y., Soltys, I. V. ... Pavlyukovich, N. (2016). Mueller-matrix mapping of optically anisotropic fluorophores of molecular biological tissues in the diagnosis of death causes. Proceedings of SPIE - The International Society for Optical Engineering, 9971, №99712L.

[16] Ushenko, Y., Grytsyuk, M., Sakhnovskiy, M., Zhytaryuk, V., Slyotov, M., Soltys, I., \& Motrich, A. (2020). Forensic medical evaluation of cerebral infarction of hemorrhagic formations of hemorrhages of traumatic genesis using polarization-phase tomography. In Fourteenth International Conference on Correlation Optics. 11369. doi: 10.1117/12.2553991

[17] Ushenko, V. A., Sdobnov, A. Y., Mishalov, W. D., Dubolazov, A. V., Olar, O. V., Bachinskyi, V. T. ... Meglinski, I. (2019). Biomedical applications of Jones-matrix tomography to polycrystalline flms of biological fuids. Journal of Innovative Optical Health Sciences, 12(6), 1950017-1-13. doi: 10.1142/ S1793545819500172

[18] Ushenko, Y. A., Trifonyuk, L. Y., Dubolazov, A. V., \& Karachevtsev, A. O. (2014). Fourier-domain Jones-matrix mapping of a complex degree of mutual anisotropy in differentiation of biological tissues' pathological states. Applied 
Optics, 53(10), B205-B214.

[19] Vanchulyak, O. Ya. (2016). Expert assessment of acute myocardial ischemia by polarization-correlation methods. Kyiv.

[20] Vanchulyak, O., Ushenko, Y., Galochkin, O., Sakhnovskiy, M., Kovalchuk, M., Dovgun, A., ... Bodnar, G. (2019). Azimuthal fractalography of networks of biological crystals. Proceedings of SPIE - The International Society for Optical Engineering., 11105, №1110517.

[21] Vanchulyak, O., Ushenko, Y., Galochkin, O., Sakhnovskiy, M., Kovalchuk, M., Dovgun, A. ... Bodnar, G. (2019). Azimuthal fractalography of networks of biological crystals. Proceedings of SPIE, 11105, Novel Optical Systems, Methods, and Applications. XXII, 1110517. (doi: 10.1117/12.2529337)

[22] Vorlou, Ch. P., Dennis, M. S., \& Gejn, Zh. (1998). Stroke. A practical guide to patient management. $\mathrm{S}$.-Pb.: Politehnika.

[23] Walsh, K. B. (2019). Non-invasive sensor technology for prehospital stroke diagnosis: Current status and future directions. Int. J. Stroke. 14(6), 592-602. doi: 10.1177/ 1747493019866621

[24] Zasler, N. D. \& Bender, S. D. (2019). Validity assessment in traumatic brain injury impairment and disability evaluations. Physical Medicine and Rehabilitation Clinics, 30(3), 621636. doi: 10.1016/j.pmr.2019.03.009

\section{ВИКОРИСТАННЯ ЛІНІЙНОГО ДИХРОЇЗМУ АЗИМУТАЛЬНО-ІНВАРІАНТНИХ МЮЛЛЕР-МАТРИЧНИХ ЗОБРАЖЕНЬ ГІСТОЛОГІЧНИХ ЗРІЗІВ РЕЧОВИНИ ГОЛОВНОГО МОЗКУ ДЛЯ ДІАГНОСТИКИ ҐЕНЕЗУ КРОВОВИЛИВУ}

Гараздюк М.С., Дуболазов О.В., Маланчук С.М.

Дифреренційна діагностика причини смерті (ПС) від ішемічного інфаркту мозку (IIM), крововиливів травматичного (КТГ) та нетравматичного (КНГ) ґенезу дозволяє виключити насильницький характер смерті. Метою роботи була розробка судовомедичних критеріїв для диференціації крововиливів травматичного та нетравматичного ґенезу та ІІМ за допомогою азимутально-інваріантних зображень матриці Мюллера лінійного дихроїзму гістологічних зрізів речовини головного мозку (РГM). Для дослідження були використані нативні зрізи РГМ від 130 трупів у разі: смерті від ішемічної хвороби серия (IXC) - 40 нативних зрізів (група 1 - контроль); КTГ - 30 зрізів (група 2), IIM - 30 зрізів (група 3), КНГ - 30 зрізів (група 4). Вимірювання значень розподілу координатних параметрів поляризації в точках мікроскопічних зображень проводилося в місці розташування стандартного стокс-поляриметра. Ефективність міжгрупової диференціації зразків мозку померлих від травматичних крововиливів та ішемічного інфраркту мозку досягає задовільного рівня і становить 76-83\%. Ефективність міжгрупової диференціації зразків у випадках смерті від крововиливів травматичного та нетравматичного генезу $є$ задовільного рівня і становить 75-82\%. Що стосується диференціації між ІІМ та КНГ, то цей метод є неефективним.

Ключові слова: крововиливи травматичного ґенезу, крововиливи нетравматичного ґенезу, ішемічний інфраркт мозку, Мюллерматричне картографрування.

\section{ИСПОЛЬЗОВАНИЕ ЛИНЕЙНОГО ДИХРОИЗМА АЗИМУТАЛЬНО-ИНВАРИАНТНЫХ МЮЛЛЕР-МАТРИЧНЫХ ИЗОБРАЖЕНИЙ ГИСТОЛОГИЧЕСКИХ СРЕЗОВ ВЕЩЕСТВА ГОЛОВНОГО МОЗГАДЛЯ ДИАГНОСТИКИ ГЕНЕЗА КРОВОИЗЛИЯНИЯ Гараздюк М.С., Дуболазов А.В., Маланчук С.М.}

Диффференциальная диагностика причины смерти (ПС) от ишемического инфаркта мозга (ИИМ), кровоизлияний травматического (КТГ) и нетравматического (КНГ) генеза позволяет исключить насильственный характер смерти. Целью работы была разработка судебно-медицинских критериев для дифрференциации кровоизлияний травматического и нетравматического генеза и ИИМ с помощью азимутально-инвариантных изображений матрицы Мюллера линейного дихроизма гистологических срезов вещества головного мозга (ВГМ). Для исследования были использованы нативные срезы ВГМ от 130 трупов в случае: смерти от ишемической болезни сердца (ИБС) - 40 нативных срезов (группа 1 контроль); КТГ - 30 срезов (группа 2), ИИМ - 30 срезов (группа 3), КНГ - 30 срезов (группа 4). Измерение значений распределения координатных параметров поляризации в точках микроскопических изображений проводили в месте расположения стандартного стокс-поляриметра. Эфффективность межгрупповой диффреренциации образцов мозга умерших от травматических кровоизлияний и ишемического инфаркта мозга достигает удовлетворительного уровня и составляет 76-83\%. Эффрективность межгрупповой дифрференциации образцов в случаях смерти от кровоизлияния травматического и нетравматического генеза является удовлетворительного уровня и составляет 75-82\%. Что касается дифрференциации между ИИМ и КНГ, то этот метод неэфорективен.

Ключевые слова: кровоизлияния травматического генеза, кровоизлияния нетравматического генеза, ишемический инфаркт мозга, Мюллер-матричное картографрирование. 